\title{
The relationship between late gadolinium enhancement imaging and myocardial biopsy in the evaluation of chronic heart failure patients with suspected myocarditis
}

\author{
Jolanta Nowak ${ }^{1,2}$, Jarosław Wasilewski ${ }^{1,2}$, Edyta Reichman-Warmusz ${ }^{3}$, Beata Spinczyk², Jan Głowacki ${ }^{2,4}$, \\ Karol Miszalski-Jamka², Oliwia Segiet ${ }^{3}$, Bożena Szyguła-Jurkiewicz ${ }^{1,2}$, Mateusz Tajstra ${ }^{2}$, \\ Arkadiusz Badziński ${ }^{5}$, Romuald Wojnicz ${ }^{2,3}$, Lech Poloński ${ }^{1,2}$
}

\author{
$13^{\text {rd }}$ Department of Cardiology in Zabrze, Medical University of Silesia, Katowice, Poland \\ 2Silesian Centre for Heart Diseases, Zabrze, Poland \\ ${ }^{3}$ Department of Histology in Zabrze, Medical University of Silesia, Katowice, Poland \\ ${ }^{4}$ Department of Radiology in Zabrze, Medical University of Silesia, Katowice, Poland \\ ${ }^{5}$ University of Silesia, Katowice, Poland
}

Kardiochirurgia i Torakochirurgia Polska 2014; 11 (4): 404-408

\begin{abstract}
Aim: The aim of this study was to assess the relationship between late gadolinium-enhanced (LGE) cardiovascular magnetic resonance (CMR) and immunohistochemical markers of inflammation in patients with heart failure and a reduced ejection fraction (HFrEF).

Material and methods: Endomyocardial biopsy and CMR were performed in 38 consecutive patients (24 males, average age $43.2 \pm 6.9$ years, New York Heart Association [NYHA] class II) with HFrEF and suspected myocarditis. The immunohistochemical evaluation was done by the En-Vision system using DAKO monoclonal antibodies. The presence of $>14$ infiltrating cells together with myocardial damage and $\geq 2+$ up-regulation of HLA class II was considered diagnostic for myocarditis. The results of LGE were compared with the immunohistochemical markers of inflammation. All patients underwent coronary angiography.

Results: Twelve out of 38 (31.6\%) patients met the immunohistological criteria for the diagnosis of myocarditis. Late gadolinium enhancement was present in 23 of 38 (60.5\%) patients, mostly at the interventricular septum. No correlation was found between LGE and immunohistochemistry results (Kendall's tau; $r=0.21, p=0.09$ ).

Conclusions: Our study revealed no significant relationship between LGE cardiovascular magnetic resonance imaging and immunohistochemical markers of inflammation in patients with HFrEF.
\end{abstract}

Key words: immunohistochemistry, cardiac magnetic resonance, myocarditis, chronic heart failure.

\section{Streszczenie}

Cel: Określenie związku między późnym wzmocnieniem pokontrastowym (late gadolinium-enhanced - LGE) w badaniu rezonansu magnetycznego serca (cardiovascular magnetic resonance - (MR) a immunohistochemicznymi wskaźnikami zapalnymi ocenianymi w wycinkach mięśnia sercowego pobranych podczas biopsji endomiokardialnej od chorych z przewlekłą niewydolnością serca i obniżoną frakcją wyrzutową lewej komory (heart failure and a reduced ejection fraction - HFrEF). Materiat i metody: Badaniem objęto 38 kolejnych chorych z HFrEF [24 mężczyzn, średni wiek 43,2 \pm 6,9 roku, w II klasie wg New York Heart Association (NYHA)] i podejrzeniem zapalenia mięśnia sercowego, u których wykonano biopsję endomiokardialną i CMR. Immunohistochemiczną ocenę wycinków mięśnia sercowego przeprowadzono z zastosowaniem metody En-Vision z użyciem przeciwciał monoklonalnych i porównano je z obecnością LGE w badaniu CMR. Za kryterium procesu zapalnego w mięśniu sercowym przyjęto obecność > 14 zapalnych komórek z uszkodzeniem miocytów i wzrost ekspresji antygenów HLA klasy $\| \geq 2+$.

Wyniki: Immunohistologiczne kryteria zapalenia mięśnia sercowego zostały spełnione u 12 z 38 (31,6\%) chorych. Obecność LGE z najczęstszą lokalizacją w okolicy przegrody międzykomorowej wykazano u 23 z 38 (60,5\%) chorych. W analizie statystycznej nie stwierdzono istotnej korelacji pomiędzy LGE a immunohistochemicznymi wskaźnikami reakcji zapalnej (Kendall's tau; $r=0,21, p=0,09$ ).

Wnioski: Badanie nie wykazało związku pomiędzy obecnością LGE w CMR a ocenianymi immunohistochemicznie wskaźnikami zapalnymi u chorych z HErEF.

Słowa kluczowe: immunohistochemia, rezonans magnetyczny serca, zapalenie mięśnia sercowego, przewlekła niewydolność serca.

Address for correspondence: Jolanta Nowak, MD, PhD, Silesian Centre for Heart Diseases, 9 Curie-Skłodowskiej St., 41-800 Zabrze, Poland, e-mail: nowjola@wp.pl 


\section{Introduction}

Numerous clinical and experimental data suggest that, irrespective of etiology, chronic low-grade inflammation may be responsible for the initiation and progression of heart failure (HF) [1-5]. Myocarditis refers to the immune response of the myocardium, and the diagnosis represents an enormous clinical challenge not only because of the diverse presentation but also due to limited sensitivity of endomyocardial biopsy. Histologic features of myocarditis in patients with HF are hampered by the focal nature of the disease and include immunological parameters of humoral and cellular autoreactivity [6]. Unlike histological features of myocarditis, which tend to be focal, immunohistological signs of inflammation are distributed throughout the entire myocardium [7]. Immunohistochemistry has a higher sensitivity compared to standard histopathology for the diagnosis of myocarditis, but the current literature regarding the relationship between the histology and cardiovascular magnetic resonance (CMR) imaging criteria is still scarce [8-12].

Non-invasive CMR was successfully introduced as a promising technique for the diagnosis of myocarditis $[13,14]$. Recent studies have demonstrated that late gadolinium enhancement (LGE) specifically reflects irreversible myocardial injury (i.e. necrosis and fibrosis) [15-17]. However, the incidence of LGE in myocarditis is still controversial, and this method does not distinguish between acute and chronic inflammation [13, 17-19]. De Cobelli et al. using the Dallas criteria found LGE to be less sensitive in "borderline" than "active" myocarditis [20]. Lurz et al. demonstrated CMR in patients with suspected chronic myocarditis not sufficient to guide clinical management [8].

The aim of this study was to assess the relationship between LGE and immunohistochemically detected markers of inflammation in patients with chronic heart failure and a reduced ejection fraction (HFrEF).

\section{Material and methods}

We studied 38 consecutive patients with stable HFrEF and high probability of myocarditis (24 males). The suspicion of myocarditis was based on variable combination of the following criteria: history of systemic viral disease or flu-like symptoms within 12 weeks before admission, clinical manifestation of heart failure (dyspnea, shortness of breath, exercise intolerance) and evidence of myocardial injury as defined by electrocardiography abnormalities (STsegment changes, conduction defects, arrhythmias) in conjunction with left ventricular dysfunction and no evidence of coronary artery disease or spasm during selective angiography and normal troponin T and creatine kinase musclebrain (CK-MB) fraction levels during index hospitalization.

The New York Heart Association (NYHA) class was used to assess functional capacity. All of our patients were on optimal medical therapy for HFrEF including an angiotensin-converting-enzyme inhibitor (captopril 50-75 mg/d), $\beta$-adrenoreceptor antagonists (metoprolol succinate, 50 to $100 \mathrm{mg} / \mathrm{d})$, spironolactone $(50-100 \mathrm{mg} / \mathrm{d})$, and furosemide (40-80 mg/d).
Transthoracic echocardiography with a $2.5 \mathrm{MHz}$ transducer (M-mode, 2D and standard Doppler echocardiography) was performed using a GE VIVID9 system. Left ventricular systolic function and left ventricular ejection fraction (LVEF) were calculated and interpreted by an experienced operator.

Cardiovascular magnetic resonance was performed with a 1.5 T scanner (Avanto; Siemens, Erlangen, Germany) using a multi-channel body-array coil as a receiver. Cine MR images were obtained in LV long-axis views, and a stack of images in the short-axis plane covering both ventricles was acquired. Ten minutes after the injection of a contrast agent (gadobenate dimeglumine, $0.1 \mathrm{mmol} / \mathrm{kg}$ ) LGE images were acquired in the same views as for cine images, using a segmented inversion recovery turbo fast-low angle shot sequence. Image analysis was performed by an experienced operator blinded to endomyocardial biopsy results.

Endomyocardial biopsy was performed using a Cordis bioptome under fluoroscopic guidance. A minimum of five samples were taken from the right side of the ventricular septum. For immunohistochemistry, specimens (at least 2 biopsies) were fixed for $20 \mathrm{~min}$ in acetone at room temperature, immersed in embedding medium (OCT Compound, Miles Inc), and stored in liquid nitrogen until tested. Frozen sections (5 $\mathrm{mm}$ thick) were incubated with murine monoclonal antihuman antibodies: anti-HLA-class II (DR antigens), $\alpha$ chain (clone TAL.1B5), anti-HLA-class I (ABC antigens), anti-CD3 for T lymphocytes (clone T3-4B5), and anti-macrophages (clone EBM11). The dilution of the primary antibody was verified in our laboratory in a series of pilot experiments. The En-Vision method (DAKO EnVision Kit/Alkaline Phosphatase detection system) was used according to the manufacturer's instructions. The bound primary antibody was detected using New Fuchsin Substrate System (DAKO A/S). The primary antibody was omitted from negative control slides. As a positive control, liver biopsy specimens from patients with chronic active hepatitis were used. The semiquantitative scoring system was defined as follows: $0-1+$, lack of or weak focal staining, 2+, moderate, multifocal staining, and 3+, severe multifocal staining. The cells positive for CD3 and CD68 were counted (NIKON Eclipse 80i microscope with DS-Fi1 digital camera and NIS Elements software from NIKON) and presented as the number of cells per $\mathrm{mm}^{2}$. The intra-observer variability of immunohistochemistry examination was $<2 \%$. For the diagnosis of myocardial inflammation we used previously published criteria [15]. The presence of more than 14 infiltrating cells with damage to the adjacent myocytes and $\geq 2+$ up-regulation of HLA class II was considered diagnostic for myocarditis. The immunohistochemistry was done by an experienced pathologist blinded to the clinical data.

The results of LGE cardiovascular magnetic resonance were compared with quantitative immunohistochemistry data.

The study protocol was approved by the local institutional Ethics Committee, and the patients gave their written informed consent. 
Tab. I. Baseline patient characteristics (values are expressed as mean \pm standard deviation)

\begin{tabular}{|c|c|}
\hline Factors* & $n=38$ \\
\hline Age (years) & $43.2 \pm 6.9$ \\
\hline Sex (male/female) & $24 / 14$ \\
\hline Heart failure duration (years) & $1.8 \pm 1.2$ \\
\hline Left ventricular ejection fraction (\%) & $38.5 \pm 13.9$ \\
\hline Left ventricular diastolic dimension (mm) & $66.2 \pm 11.4$ \\
\hline Left ventricular systolic dimension (mm) & $59.7 \pm 13.8$ \\
\hline Troponin T (ng/ml) & $0.011 \pm 0.008$ \\
\hline CK-MB fraction (ng/ml) & $3.3 \pm 0.05$ \\
\hline $\begin{array}{l}N \text {-terminal prohormone of brain } \\
\text { natriuretic peptide (NT-proBNP) }(\mathrm{pg} / \mathrm{ml}) \text {, } \\
\text { median ( } 1^{\text {st }} 3^{\text {rd }} \text { quartile) }\end{array}$ & $612(373.2-1919.5)$ \\
\hline $\begin{array}{l}\text { C-reactive protein }(\mathrm{mg} / \mathrm{l}) \text {, } \\
\text { median }\left(1^{\text {st }}-3^{\text {rd }} \text { quartile }\right)\end{array}$ & $2.2(1.1-4.9)$ \\
\hline
\end{tabular}

\section{Statistical analysis}

The normally distributed data were presented as mean with SD, but non-normally distributed data were described with the median and interquartile range. To assess the relationship between quantitative data, Spearman's rankorder coefficient rho was used. Kendall's tau rank-correlation coefficient test was used to assess the relationship between semi-quantitative data. Statistical analyses were performed using the SPSS software package, v. 16.0.

\section{Results}

The selected demographic, echocardiographic and laboratory data are displayed in Table I. The mean age within the population was $43.2 \pm 6.9$. For the overall group of patients, the average duration of symptoms was 2.6 years, and all the patients were in NYHA class II.

By immunohistochemistry, moderately increased HLA-class I molecules (2+) were present in biopsy speci-

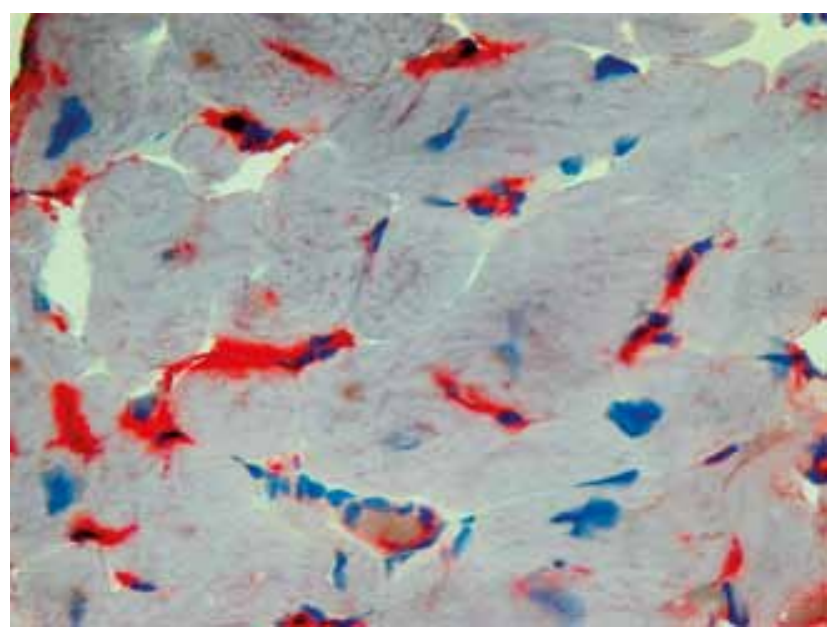

Fig. 1. Immunohistochemical staining of HLA-DR antigens. Note the red staining pattern by hematoxylin (blue) at $400 \times$ magnification mens of 11 (28.9\%) patients, but severe up-regulation (3+) was found in 14 (36.8\%) patients. Similarly, moderate up-regulation of HLA-class II (Fig. 1) was found in 14 of 38 $(36.8 \%)$ cases, but its severe expression was observed in $4(10.5 \%)$ patients. Infiltrating CD68 (+) cells (Fig. 2) outnumbered CD3 (+) lymphocytes. The number of CD3 (+) lymphocytes $>14$ cells per $\mathrm{mm}^{2}$ was found in 2 of 38 (5.3\%) patients. By contrast, the number of CD68 (+) cells > 14 per $\mathrm{mm}^{2}$ was detected in 14 (36.8\%) patients. A total of 12 (31.6\%) patients met the criteria for myocarditis. Kendall's tau analysis showed that HLA-class I expression significantly correlated with HLA-class II $(r=0.7, p<0.001)$ and the number of CD68 $(+)$ cells $(r=$ $0.3, p=0.005)$. There was no correlation between HLAclass II and CD68 and CD3 (+) cells as well as between CD68 (+) and CD3 (+) cells (Spearman's rho; $r=0.17$, $p=0.16)$. Within the total population, subepicardial LGE was diagnosed in 23 of $38(60.5 \%)$ patients, mostly in the interventricular septum. No correlation was found between LGE (Fig. 3) and immunohistochemical markers of inflammation (Kendall's tau; $r=0.21, p=0.09$ ).

\section{Discussion}

To the best of our knowledge, this is the first prospective study on LGE and immunohistochemistry in patients with HFrEF. The main findings of the present study can be summarized as follows. Firstly, we demonstrated in patients with stable HFrEF the histological criteria of myocarditis in about $30 \%$ of our cohort. Secondly, LGE imaging revealed myocardial fibrosis in more than half of them. Furthermore, there was no statistically significant association between immunohistochemical markers of inflammation and LGE.

Myocarditis is a cardiac disease associated with inflammation and injury to the myocardium, but the pathophysiological process is still poorly understood. Standardized immunohistological criteria are well defined in the diagnosis of acute myocarditis [9, 21, 22]. On the other hand, there are no sensitive diagnostic criteria for the chronic phase

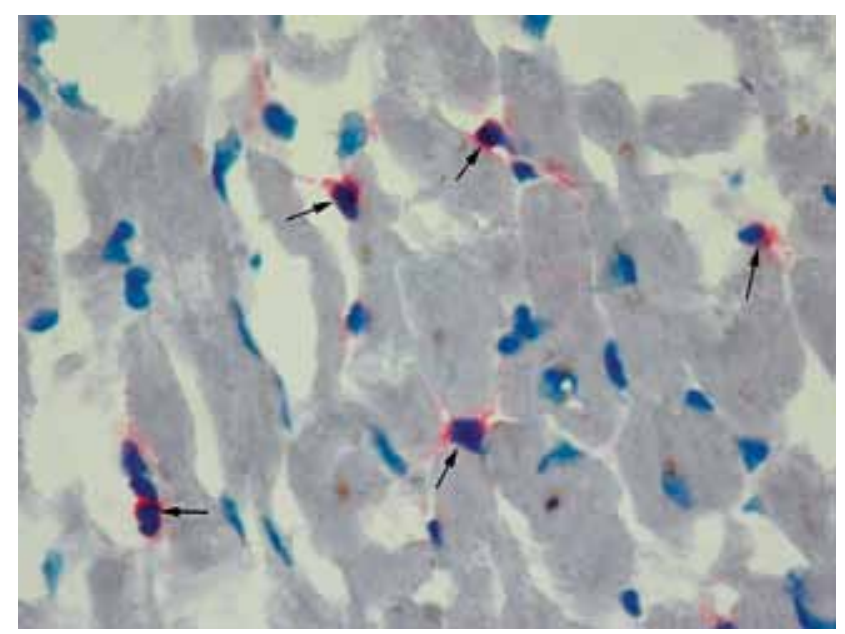

Fig. 2. Typical focal type of the CD3 lymphocyte infiltration (arrows) 

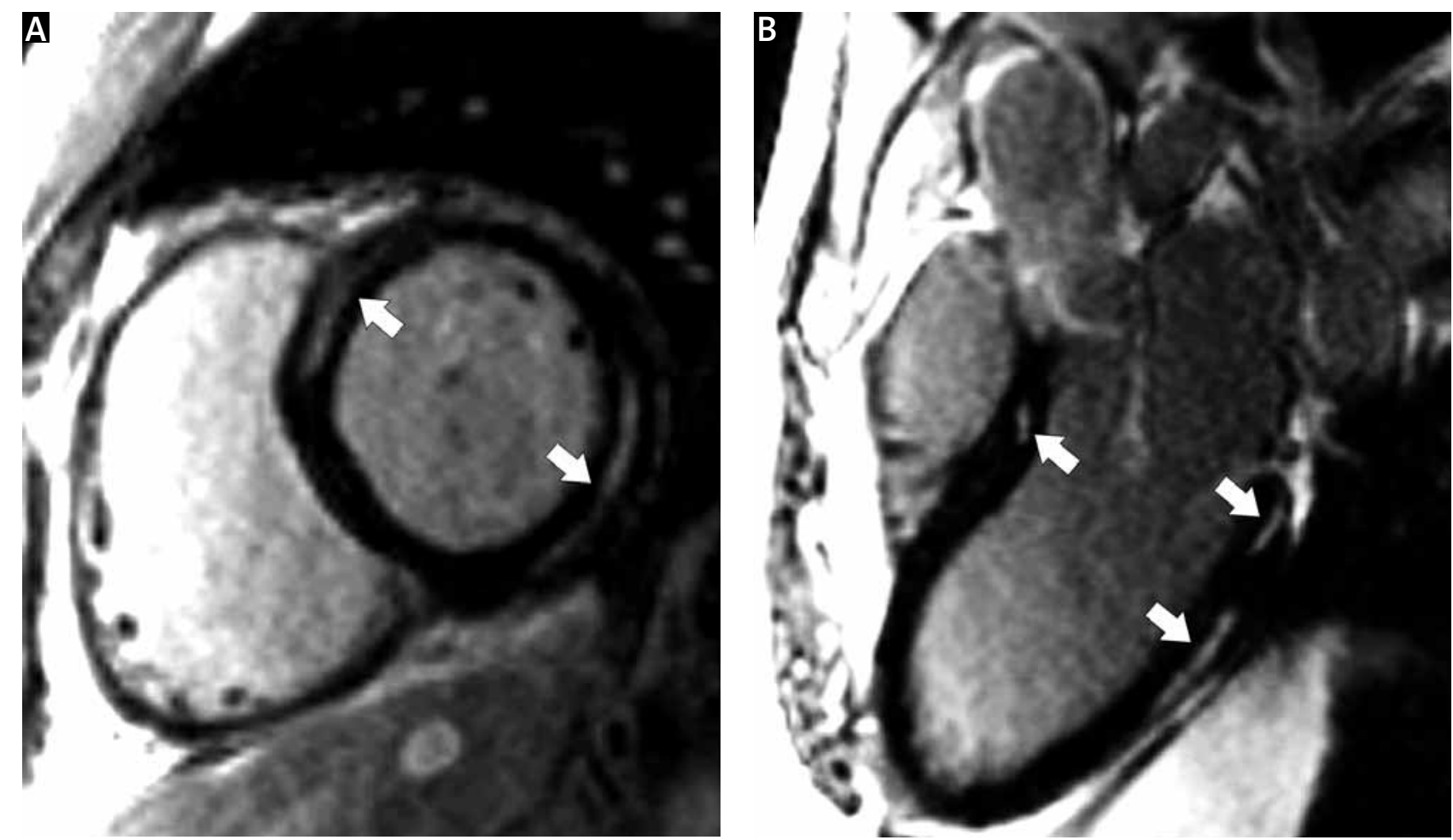

Fig. 3. Magnetic resonance. Short-axis (A) and long-axis (B) demonstrate the presence of typical late gadolinium enhancement in the subepicardium of the left mid-ventricular lateral wall and the basal septum (arrows)

of myocardial injury. Since chronic intramyocardial inflammation was previously found in patients with $\mathrm{HF}$, it is likely that systolic heart failure is one of its clinical presentations [4]. In our study group, the immunohistochemical criteria of myocarditis were established in $31.6 \%$ of the evaluated patients. However, Lurz et al. found a $48 \%$ prevalence of myocarditis in patients with chronic myocarditis [8]. Mavrogeni et al. documented that endomyocardial biopsy using immunohistological criteria was positive in $48 \%$ of patients with a clinical suspicion of myocarditis and symptoms lasting over 14 days [23].

The late enhancement is a consequence of pathological intracellular contrast uptake related to the sarcolemmal rupture that occurs in the presence of cardiomyocyte damage and has been shown to be superior to other modalities used for the detection of myocardial necrosis [19]. Friedrich et al. provided recommendations on the use of LGE and novel approaches, such as time-resolved assessment of gadolinium wash-out, T1 mapping, T2 mapping, parametric imaging, and the combination of imaging criteria as part of the diagnostic process in patients with suspected myocarditis [13]. The main limitation of LGE is the variable sensitivity to detect active or chronic myocarditis, depending on the patient characteristics $[15-17,20]$. Our study revealed that LGE was present in $60.5 \%$ of patients with $\mathrm{HFrEF}$, which is slightly higher than in the previous study in patients with viral myocarditis [24]. Furthermore, studies concerning the usefulness of CMR in myocarditis had a low number of patients, and the enrollment started at variable time points after the clinical onset of the disease. Addition- ally, the authors adopted different criteria of myocarditis. Contrary to previous reports related to patients with acute myocarditis, we did not reveal a significant relationship between the presence of LGE and immunohistochemical markers of inflammation [8, 12]. The most likely explanation of our results is that we studied a population with long-lasting clinical manifestations of HF, and LGE was related to the fibrotic areas which develop as a consequence of myocarditis.

The study is limited due to the small number of enrolled patients. However, we are of the opinion that our study reflects a real-world clinical setting. A notable strength is the direct comparison between LGE and immunohistochemistry. However, biopsy specimens were obtained from the subendocardial layer and may not represent the areas involving subepicardial and mesocardial layers typical of fibrosis in the course of myocarditis.

\section{Conclusions}

The lack of a relationship between LGE imaging and immunohistochemical markers of inflammation in patients with stable HFrEF indicates that LGE might reflect postinjury necrosis rather than an acute inflammatory process. Further studies are needed to define the capacity of CMR in patients with HFrEF.

\section{Acknowledgements}

This work was supported by the grants from the Medical University of Silesia KNW-1-124/09, KNW-1-141/10 and KNW -1-152/P/1/0. 


\section{Disclosure}

Authors report no conflict of interest.

\section{References}

1. Cetta F, Michels VV. The autoimmune basis of dilated cardiomyopathy. Ann Med 1995; 27: 169-173.

2. Aukrust P, Ueland T, Lien E, Bendtzen K, Müller F, Andreassen AK, Nord øy I, Aass H, Espevic T, Simonsen S, Frøland SS, Gullestand L. Cytokine network in congestive heart failure secondary to ischemic or idiopathic dilated cardiomyopathy. Am J Cardiol 1999; 83: 376-382.

3. Hasper D, Hummel M, Kleber FX, Reindl I, Volk HD. Systemic inflammation in patients with heart failure. Eur Heart J 1998; 19: 761-765.

4. Devaux B, Scholz D, Hirche A, Klövekorn WP, Schaper J. Upregulation of cell adhesion molecules and the presence of low grade inflammation in human chronic heart failure. Eur Heart J 1997; 18: 470-479.

5. Klappacher G, Mehrabi M, Franzen P, Plesch K, Binder M, Haab D, Urban S, Laufer G, Glogar HD, Eichler HG. Endomyocardial HLA expression is increased to the same extent in idiopathic and secondary dilated cardiomyopathy. Immunol Lett 1994; 41: 59-66.

6. Maisch B, Bauer E, Hufnagel G, Pfeifer U, Rohkamm R. The use of endomyocardial biopsy in heart failure. Eur Heart J 1988; 9: 59-71.

7. Noutsias M, Seeberg B, Schultheiss HP, Kuhl U. Expression of cell adhesion molecules in dilated cardiomyopathy. Evidence for endothelial activation in inflammatory cardiomyopathy. Circulation 1999; 99: 2124-2131.

8. Lurz P, Eitel I, Adam J, Steiner J, Grothoff M, Desch S, Fuernau G, de Waha S, Sareban M, Luecke C, Klingel K, Kandolf R, Schuler G, Gutberlet M, Thiele H. Diagnostic performance of CMR imaging compared with $E M B$ in patients with suspected myocarditis. J Am Coll Cardiol Imag 2012; 5: 513-524.

9. Herskowitz A, Ahmed-Ansari A, Neumann DA, Beschorner WE, Rose NL, Soule LM, Burek CL, Sell K, Baughman K. Induction of major histocompatibility complex antigens within the myocardium of patients with active myocarditis: a nonhistologic marker of myocarditis. J Am Coll Cardiol 1990; 15: 624-632.

10. Angelini A, Crosato M, Boffa GM, Calabrese F, Calzolari V, Chioin R, Daliento L, Thiene G. Activ versus borderline myocarditis: clinicopathological correlates and prognostic implications. Heart 2002; 87: 210-215.

11. Cocker M, Friedrich MG. Cardiovascular magnetic resonance of myocarditis. Curr Cardiol Rep 2010; 12: 82-89.

12. Francone M, Chimenti C, Galea N, Scopelliti F, Verardo R, Galea R, Carbone I, Catalano C, Fedele F, Frustaci A. CMR Sensitivity varies with clinical presentation and extent of cell necrosis in biopsy-proven acute myocarditis. J Am Coll Cardiol Cardiovasc Imaging 2014; 7: 254-263.
13. Friedrich MG, Sechtem U, Schulz-Menger J, Holmvang G, Alakija P, Cooper LT, White JA, Abdel-Aty H, Gutberlet M, Prasad S, Aletras A, Laissy JP, Paterson I, Filipchuk NG, Kumar A, Pauschinger M, Liu P. Cardiovascular magnetic resonance in myocarditis: a JACC White Paper. J Am Coll Cardiol 2009; 53: 1475-1487.

14. Baccouche H, Mahrholdt H, Meinhardt G, Meinhardt G, Merher R, Voehringer M, Hill S, Klingel K, Kandolf R, Sechtem U, Yilmaz A. Diagnostic synergy of non-invasive cardiovascular magnetic resonance and invasive endomyocardial biopsy in troponin-positive patients without coronary artery disease. Eur Heart J 2009; 30: 2869-2879.

15. Mahrholdt H, Wagner A, Deluigi CC, Kispert E, Hager S, Meinhardt G, Vogelsberg H, Fritz P, Dippon J, Bock T, Klingel K, Kandolf R, Sechtem U. Presentation, patterns of myocardial damage, and clinical course of viral myocarditis. Circulation 2006; 114: 1581-1590.

16. Abdel-Aty $\mathrm{H}$, Boyé $\mathrm{P}$, Zagrostek A, Wassmuth R, Kumar A, Messroghli D, Bock P, Dietz R, Friedrich MG, Schulz-Menger J. Diagnostic performance of cardiovascular magnetic resonance in patients with suspected acute myocarditis: Comparision of different approaches. J Am Coll Cardiol 2005; 45: 1815-1822.

17. Mahrholdt H, Goedecke Ch, Wagner A, Meinhardt G, Athanasiadis A, Vogelsberg H, Fritz P, Klingel K, Kandolf R, Sechtem U. Cardiovascular magnetic resonance assessment of human myocarditis: a comparison to histology and molecular pathology. Circulation 2004; 109: 1250-1258.

18. Rieker O, Mohrs O, Obelholzer K, Kreitner KF, Thelen M. Cardiac MRI in suspected myocarditis (in German). Rofo Fortschr Geb Rontgenstr Neuen Bildgeb Verfar 2002; 174: 1530-1536.

19. Gutberlet M, Spors B, Thoma T. Bertram H, Denecke T, Felix R, Noutsias M, Schultheiss HP, Kühl U. Suspected chronic myocarditis at cardiac MR: diagnostic accuracy and association with immunohistologically detected inflammation and viral persistence. Radiology 2008; 246: 401-409.

20. De Cobeli F, Pieroni M, Esposito A, Chimenti C, Belloni E, Mellone R, Canu T, Perseghin G, Gaudio C, Maseri A, Frustaci A, Del Maschio A. Delayed gadolinium-enhanced cardiac magnetic resonance in patients with chronic myocarditis presenting with heart failure or recurrent arrhythmias. J Am Coll Cardiol 2006; 47: 1649-1654.

21. Cooper LT Jr. Myocarditis. N Engl J Med 2009; 360: 1526-1538.

22. Aretz HT. Myocarditis: The Dallas criteria. Hum Pathol 1987; 18: 619-624.

23. Mavrogeni S, Spargias C, Bratis C, Kolovou G, Markussis V, Papadopoulou E, Costadoulakis P, Papadimitropoulos M, Douskou M, Pavlides G, Cokkinos D. Myocarditis as a precipitating factor for heart failure: evaluation and 1-year follow-up using cardiovascular magnetic resonance and endomyocardial biopsy. Eur J Heart Fail 2011; 13: 830-837.

24. Grün S, Schumm J, Greulich S, Wagner A, Schneider S, Bruder O, Kispert EM, Hill S, Ong P, Klingel K, Kandolf R, Sechtem U, Merholdt H. Long-term followup of biopsy-proven viral myocarditis. J Am Coll Cardiol 2012; 59: 1604-1615. 